\title{
Base-Free Synthesis of Furfurylamines from Biomass Furans Using Ru Pincer Complexes
}

\author{
Danielle Lobo Justo Pinheiro (D) and Martin Nielsen *๑ \\ Department of Chemistry, Technical University of Denmark, DK-2800 Kgs. Lyngby, Denmark; dane@kemi.dtu.dk \\ * Correspondence: marnie@kemi.dtu.dk; Tel.: +45-24651045
}

\begin{abstract}
We report the first example of employing homogeneous organometal-catalyzed transfer hydrogenation for the selective reductive amination of furfurals to furfurylamines. An efficient, chemoselective, and base-free method is described using Ru-MACHO-BH as catalyst and $i \mathrm{PrOH}$ as $\mathrm{H}$ donor. The method tolerates a range of substituents affording moderate to excellent yields.
\end{abstract}

Keywords: transfer hydrogenation; furfurals; furfurylamine; reductive amination; Ru-MACHO

Citation: Pinheiro, D.L.J.; Nielsen, M. Base-Free Synthesis of

Furfurylamines from Biomass Furans Using Ru Pincer Complexes. Catalysts 2021, 11, 558. https://doi.org/ $10.3390 /$ catal11050558

Academic Editors:

Raffaele Cucciniello, Daniele Cespi and Tommaso Tabanelli

Received: 30 March 2021

Accepted: 26 April 2021

Published: 28 April 2021

Publisher's Note: MDPI stays neutral with regard to jurisdictional claims in published maps and institutional affiliations.

\section{Introduction}

The development of sustainable techniques to transform biomass into useful compounds is one of the biggest challenges of modern chemistry [1]. The introduction of nitrogen in biomass-derived compounds adds value and expands their industry applicability [2]. Furfurals are aldehydes derived from biomass and are identified as one of the key chemicals produced by the lignocellulosic biorefineries. Around $280 \mathrm{kTon}$ are produced globally per year [3]. Furfurylamines (amines derived from furfurals) present diverse applications in the industry, including the preparation of pharmaceutical compounds such as Furesomide, Furtrethonium, an anti-hepatitis-B, and Barmastine (Figure 1), as well as polymers, antiseptic agents, agrochemicals, pesticides, and synthetic resins $[1,2,4]$.
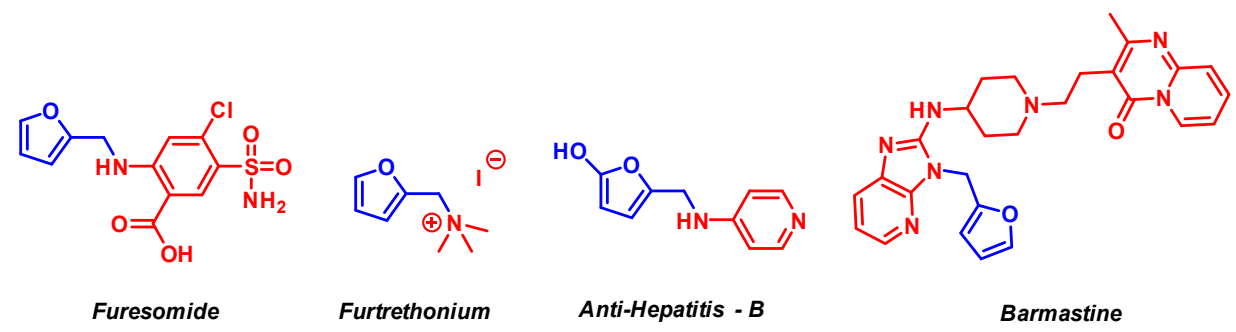

Figure 1. Pharmaceutical compounds containing furfurylamines.

The synthesis of furfurylamines from furfurals by reductive amination has been investigated using diverse reducing agents and catalysts. Studies involving hydrogen gas, silanes, borohydrides, and formic acid as reductants have been reported in the literature. Hydrogen gas as reductant is an interesting green tool; however, the method needs to operate under pressure of a highly flammable gas, increasing the operating cost. Nevertheless, there are many examples in the literature using $\mathrm{H}_{2}$ as reductant for reductive amination with noble and non-noble metal catalysts such as $\mathrm{Ru}, \mathrm{Au}, \mathrm{Ir}, \mathrm{Pt}, \mathrm{Ni}, \mathrm{Co}$ and Fe [5-11]. Although silane is obtained from waste residues of the silicon industry, their use is still in stoichiometric amounts, generating excessive amounts of waste [12-14]. The use of formic acid as $\mathrm{H}$ donor for the reductive amination of furfural was demonstrated as well. Cao and co-workers synthesized $\mathrm{N}$-(furan-2-ylmethyl)aniline in 93\% yield from nitrobenzene and furfural using $\mathrm{Au} / \mathrm{TiO}_{2}-\mathrm{R}$ as catalyst at $80^{\circ} \mathrm{C}$ for $4 \mathrm{~h} \mathrm{[15].} \mathrm{Smith} \mathrm{Jr} \mathrm{and} \mathrm{co-workers} \mathrm{also}$ employed formic acid as $\mathrm{H}$ donor, but used formamide as $\mathrm{N}$ source [16]. To the best of our 
knowledge, the only work involving an alcohol as $\mathrm{H}$ donor $(i \mathrm{PrOH})$ for the synthesis of furfurylamines from furfural was reported by Yus [17]. In this work, the reaction between furfural and heptylamine using $20 \mathrm{~mol} \%$ of NiNPs at $76^{\circ} \mathrm{C}$ for $48 \mathrm{~h}$ afforded $30 \%$ yield of the furfurylamine.

One of the most powerful and robust methods for effective $\mathrm{C}-\mathrm{N}$ bond formation of amines is the reductive amination of carbonyl compounds. [4,18-30]. This transformation features compelling advantages, such as simple operating setups, mild reaction conditions, direct use of available substrates, and inexpensive reagents [31]. The reductive amination using transfer hydrogenation for the synthesis of furfurylamines from furfurals is limited, even though this transformation as a synthetic tool is non-toxic, environmentally friendly, does not require flammable gasses, and employs a stable, easy to handle, and inexpensive source of hydrogen [4,32-37]. However, transfer hydrogenation catalysts typically require strong bases to be active, which can be detrimental for substrates that are base-sensitive [38]. Therefore, studies applying base-free conditions must be developed to avoid this drawback.

The use of homogenous metal catalysis has demonstrated great reactivity for transfer hydrogenation of carbonyl compounds and has been proven to hold many advantages [38-41]. In 2018, De Vries reported a base-free transfer hydrogenation of $\alpha, \beta-$ unsaturated ketones and aldehydes using the PNP pincer complex carbonylhydrido (tetrahydroborato)[bis(2-diphenylphosphinoethyl)amino]ruthenium(II) (Ru-MACHO-BH) as catalyst, in the presence of EtOH or $\mathrm{PrOH}$ as $\mathrm{H}$ source and showed high activity and selectivity [42]. The amino-based Ru-PNP complexes are also very efficient catalysts for hydrogenation [43-49] and dehydrogenation [50-57] reactions. The high activity of these $\mathrm{Ru}$ PNP complexes in hydrogenations is often attributed to the presence of the $\mathrm{Ru}-\mathrm{H}$ unit and N-H group [58].

Inspired by these works, we investigated the use of Ru-MACHO [59] (carbonylhydrido (tetrahydroborato)[bis(2-diphenylphosphinoethyl)amino]ruthenium(II)) and Ru-MACHO$\mathrm{BH}$ complexes as potential catalysts for the transfer hydrogenation of the reductive amination in this work.

\section{Results and Discussion}

Our studies commenced with testing Ru-MACHO ( $1 \mathrm{~mol} \%$ ) as the catalyst for the transfer hydrogenation of the aldimine 1a (Figure S1) in the presence of $i \mathrm{PrOH}(0.2 \mathrm{M}$ of $1 \mathrm{a})$ as hydrogen source and $\mathrm{KOtBu}(20 \mathrm{~mol} \%)$ as additive at $90{ }^{\circ} \mathrm{Cfor} 3 \mathrm{~h}$ (Scheme 1$)$. To our delight, the reaction afforded $>99 \%$ conversion to furfurylamine $2 \mathrm{a}$. We then set out to evaluate the transfer hydrogenation of $1 \mathbf{a}$ using varying catalyst loading, additives, temperatures, and reaction times with the aim of developing a mild protocol for this reaction.

a)
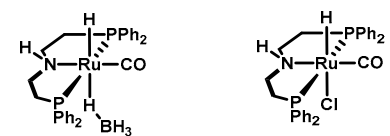

RU-MACHO-BH RU-MACHO

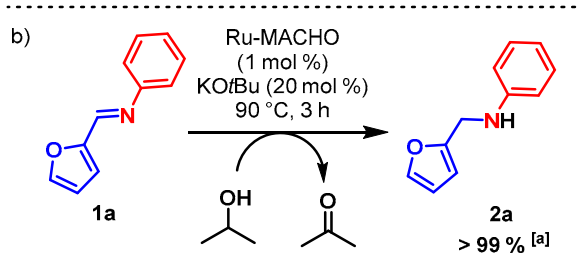

Scheme 1. (a) Ru-PNP catalysts used in this work. (b) Transfer hydrogenation of aldimine using Ru-MACHO. ${ }^{[a]}$ Measured by ${ }^{1} \mathrm{H}$ NMR spectroscopy analysis of the crude reaction mixture.

Reducing the reaction time to $15 \mathrm{~min}$, the catalyst loading of Ru-MACHO to $0.5 \mathrm{~mol} \%$, and the $\mathrm{KO} t \mathrm{Bu}$ loading to $10 \mathrm{~mol} \%$ still led to full conversion (Table 1, Entry 3). In fact, after $5 \mathrm{~min}, 51 \%$ was already converted (Entry 4). Changing the additive to $\mathrm{NaOH}$ had 
a detrimental effect, and only $18 \%$ conversion was observed. Likewise, lowering the catalyst loading to $0.1 \mathrm{~mol} \%$ afforded less than $5 \%$ conversion. Changing the catalyst to Ru-MACHO-BH showed very low activity within $15 \mathrm{~min}$, both with and without additive (Entries 6 and 7, respectively).

Table 1. Transfer hydrogenation of aldimines: Initial studies.

\begin{tabular}{ccccc}
\hline Entry $^{\mathbf{a}}$ & Catalyst (mol\%) & Additive $^{\mathbf{b}}$ & Time & Conv. $^{\mathbf{c}} \mathbf{( \% )}$ \\
\hline 1 & Ru-MACHO (0.5) & KOtBu & $1 \mathrm{~h}$ & $>99$ \\
2 & Ru-MACHO (0.5) & KOtBu & $30 \mathrm{~min}$ & $>99$ \\
3 & Ru-MACHO (0.5) & KOtBu & $15 \mathrm{~min}$ & $>99$ \\
4 & Ru-MACHO (0.5) & KOtBu & $5 \mathrm{~min}$ & 51 \\
5 & Ru-MACHO (0.5) & $\mathrm{NaOH}$ & $15 \mathrm{~min}$ & 18 \\
6 & Ru-MACHO (0.1) & KOtBu & $15 \mathrm{~min}$ & $<5$ \\
7 & Ru-MACHO-BH (0.5) & - & $15 \mathrm{~min}$ & $<5$ \\
\hline
\end{tabular}

a Reactions were carried out using $1.3 \mathrm{mmol}$ of furfural and aniline in $7 \mathrm{~mL} i \mathrm{PrOH}$ at $90^{\circ} \mathrm{C} .{ }^{\mathrm{b}} 10 \mathrm{~mol} \%$ additive used. ${ }^{c}$ Measured by ${ }^{1} \mathrm{H}$ NMR spectroscopy analysis of the crude reaction mixture.

Motivated by these initial positive results, the reductive amination of furfural with aniline was further investigated. Thus, in the presence of $10 \mathrm{~mol} \% \mathrm{KO} t \mathrm{Bu}, 0.5 \mathrm{~mol} \%$ of Ru-MACHO afforded $>99 \%$ conversion after $18 \mathrm{~h}$ at $90^{\circ} \mathrm{C}$. However, the furfuryl alcohol (FA, 3) appeared as a significant side product in a proportion of 7:3 (2a/3) (Scheme 2). Fortunately, introducing $\mathrm{MgSO}_{4}$ as drying agent led to $>99 \%$ conversion selectively to the desired product in $3 \mathrm{~h}$ (Table 2, Entry 2). Reducing the reaction time to $1 \mathrm{~h}$ decreased the selectivity to 93:7. Using Ru-MACHO-BH (0.5 mol\%) and $\mathrm{MgSO}_{4}$ but without the basic additive still resulted in $93 \%$ conversion after $1 \mathrm{~h}$ and with $\mathbf{2 a}$ as the sole product by ${ }^{1} \mathrm{H}$ NMR analysis (Entry 3). Increasing the amount of aniline from 1.0 to 1.2 equivalent afforded $>99 \%$ 2a under otherwise identical conditions (Entry 5). Unfortunately, it was not possible to further reduce the reaction time without compromising the conversion and selectivity (Entries 6-8). Decreasing the amount of Ru-MACHO-BH to $0.25 \mathrm{~mol} \%$ also led to a low conversion of $11 \%$ (Entry 9). Lowering the temperature to $70{ }^{\circ} \mathrm{C}$ resulted in practically no conversion $(<5 \%$, Entry 10$)$. However, by increasing the temperature to $120^{\circ} \mathrm{C}$, it was possible to achieve exclusively $2 \mathrm{a}$ with $>99 \%$ conversion within $30 \mathrm{~min}$ (Entry 11).

A number of drying agents were then tested. Using $\mathrm{Na}_{2} \mathrm{SO}_{4}$ at $90{ }^{\circ} \mathrm{C}$ afforded $>99 \%$ conversion in $1 \mathrm{~h}$. However, the selectivity decreased to 97:3 (2a/3) (Entry 12). Decreasing the time further to $15 \mathrm{~min}$ maintained the full conversion but led to even lower selectivity, down to 57:42 (2a/3) (Entries 13-15). These observations suggest that the formation of $\mathbf{3}$ is highly reversible, and that $1 \mathrm{a}$ is regenerated from 3 throughout the course of the reaction. Moreover, decreasing the reaction temperature to $70{ }^{\circ} \mathrm{C}$ led to merely $17 \%$ conversion (Entry 16). Molecular sieves (4 $⿱$ ) were also evaluated and showed full conversion after $1 \mathrm{~h}$, albeit with slightly lower selectivity (94:6 2a/3) (Entry 17). Decreasing the time further to $15 \mathrm{~min}$ maintained the full conversion but also led to lower selectivity, (71:29 2a/3) (Entry 18). The temperature was evaluated, and carrying out the reaction at $70{ }^{\circ} \mathrm{C}$ led to $71 \%$ conversion and $96: 4(\mathbf{2 a} / \mathbf{3})$ of selectivity (Entry 19$)$.

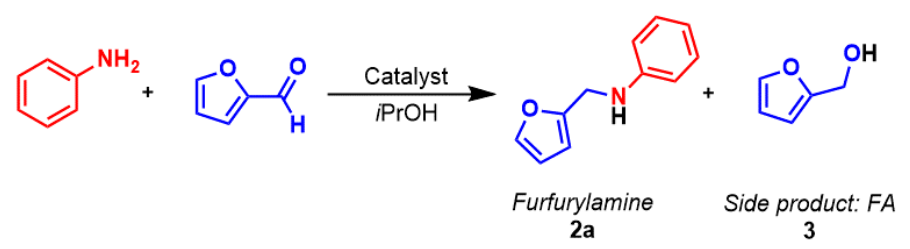

Scheme 2. Reductive amination between furfural and aniline. 
Table 2. One-pot synthesis of furfurylamines: Optimization.

\begin{tabular}{|c|c|c|c|c|c|c|c|}
\hline Entry $^{a}$ & Catalyst (mol\%) & Additive $^{b}$ & Temperature $\left({ }^{\circ} \mathrm{C}\right)$ & Time & Conversion $^{c}(\%)$ & $2 a^{c}(\%)$ & $3^{c}(\%)$ \\
\hline 1 & Ru-MACHO (0.5) & $\mathrm{KO} t \mathrm{Bu}$ & 90 & $18 \mathrm{~h}$ & $>99$ & 70 & 30 \\
\hline 2 & Ru-MACHO (0.5) & $\mathrm{KO} t \mathrm{Bu}+\mathrm{MgSO}_{4}$ & 90 & $3 \mathrm{~h}$ & $>99$ & $>99$ & - \\
\hline 3 & Ru-MACHO (0.5) & $\mathrm{KO} t \mathrm{Bu}+\mathrm{MgSO}_{4}$ & 90 & $1 \mathrm{~h}$ & $>99$ & 93 & 7 \\
\hline 4 & Ru-MACHO-BH (0.5) & $\mathrm{MgSO}_{4}$ & 90 & $1 \mathrm{~h}$ & 93 & $>99$ & - \\
\hline $5^{d}$ & Ru-MACHO-BH (0.5) & $\mathrm{MgSO}_{4}$ & 90 & $1 \mathrm{~h}$ & $>99$ & $>99$ & - \\
\hline $6^{\mathrm{d}}$ & Ru-MACHO-BH (0.5) & $\mathrm{MgSO}_{4}$ & 90 & $45 \min$ & 75 & 86 & 14 \\
\hline $7^{d}$ & Ru-MACHO-BH (0.5) & $\mathrm{MgSO}_{4}$ & 90 & $30 \mathrm{~min}$ & 30 & 73 & 27 \\
\hline $8^{\mathrm{d}}$ & Ru-MACHO-BH (0.5) & - & 90 & $30 \mathrm{~min}$ & 15 & 52 & 48 \\
\hline $9^{d}$ & Ru-MACHO-BH (0.25) & $\mathrm{MgSO}_{4}$ & 90 & $1 \mathrm{~h}$ & 11 & - & $>99$ \\
\hline $10^{\mathrm{d}}$ & Ru-MACHO-BH (0.5) & $\mathrm{MgSO}_{4}$ & 70 & $1 \mathrm{~h}$ & $<5$ & - & - \\
\hline $11^{\mathrm{d}}$ & Ru-MACHO-BH (0.5) & $\mathrm{MgSO}_{4}$ & 120 & $30 \mathrm{~min}$ & $>99$ & $>99$ & - \\
\hline $12^{d}$ & Ru-MACHO-BH (0.5) & $\mathrm{Na}_{2} \mathrm{SO}_{4}$ & 90 & $1 \mathrm{~h}$ & $>99$ & 97 & 3 \\
\hline $13^{d}$ & Ru-MACHO-BH (0.5) & $\mathrm{Na}_{2} \mathrm{SO}_{4}$ & 90 & $45 \mathrm{~min}$ & $>99$ & 90 & 10 \\
\hline $14^{\mathrm{d}}$ & Ru-MACHO-BH (0.5) & $\mathrm{Na}_{2} \mathrm{SO}_{4}$ & 90 & $30 \mathrm{~min}$ & $>99$ & 76 & 24 \\
\hline $15^{\mathrm{d}}$ & Ru-MACHO-BH (0.5) & $\mathrm{Na}_{2} \mathrm{SO}_{4}$ & 90 & $15 \mathrm{~min}$ & $>99$ & 57 & 42 \\
\hline $16^{\mathrm{d}}$ & Ru-MACHO-BH (0.5) & $\mathrm{Na}_{2} \mathrm{SO}_{4}$ & 70 & $1 \mathrm{~h}$ & 17 & 72 & 28 \\
\hline $17^{\mathrm{d}}$ & Ru-MACHO-BH (0.5) & MS $4 \AA$ & 90 & $1 \mathrm{~h}$ & $>99$ & 94 & 6 \\
\hline $18^{\mathrm{d}}$ & Ru-MACHO-BH (0.5) & MS $4 \AA$ & 90 & $15 \mathrm{~min}$ & $>99$ & 71 & 29 \\
\hline $19^{d}$ & Ru-MACHO-BH (0.5) & MS $4 \AA$ & 70 & $1 \mathrm{~h}$ & 71 & 96 & 4 \\
\hline
\end{tabular}

${ }^{a}$ Reactions were carried out using $1.3 \mathrm{mmol}$ of furfural, aniline, and $1.3 \mathrm{mmol}$ of drying agent in $7 \mathrm{~mL} i \mathrm{PrOH} .{ }^{\mathrm{b}} 10 \mathrm{~mol} \%$ of $\mathrm{KOtBu}$ used. ${ }^{\mathrm{c}}$ Measured by ${ }^{1} \mathrm{H}$ NMR spectroscopy analysis of the crude reaction mixture. ${ }^{\mathrm{d}}$ Reactions were carried out using 1.2 equivalent of aniline. MS $=$ Molecular sieves.

As seen in Figure 2, the levels of 1-3 differed significantly throughout the course of the reaction, depending on whether $\mathrm{Na}_{2} \mathrm{SO}_{4}$ or $\mathrm{MgSO}_{4}$ was employed. Within $15 \mathrm{~min}$, almost all 1a had disappeared and $60 \%$ of $2 \mathrm{a}$ had already been generated when using $\mathrm{Na}_{2} \mathrm{SO}_{4}$. Surprisingly, $35 \%$ of 3 was observed at this point. Hereafter, the reaction slowed significantly, and after $30 \mathrm{~min}$, merely $70 \%$ of $\mathbf{2 a}$ had been produced and $\mathbf{3}$ had only dropped to $22 \%$. By contrast, with $\mathrm{MgSO}_{4}$ the level of 3 did not exceed $15 \%$ throughout the entire course of the reaction, and after $30 \mathrm{~min}$, it was $12 \%$. At this time, there was still an ample amount of $1 \mathbf{a}(45 \%)$ to undergo hydrogenation, and $43 \%$ of $\mathbf{2 a}$ had been produced. This difference in amount of 1a present during the course of the reaction might explain the superiority of $\mathrm{MgSO}_{4}$ as drying agent after $60 \mathrm{~min}$.
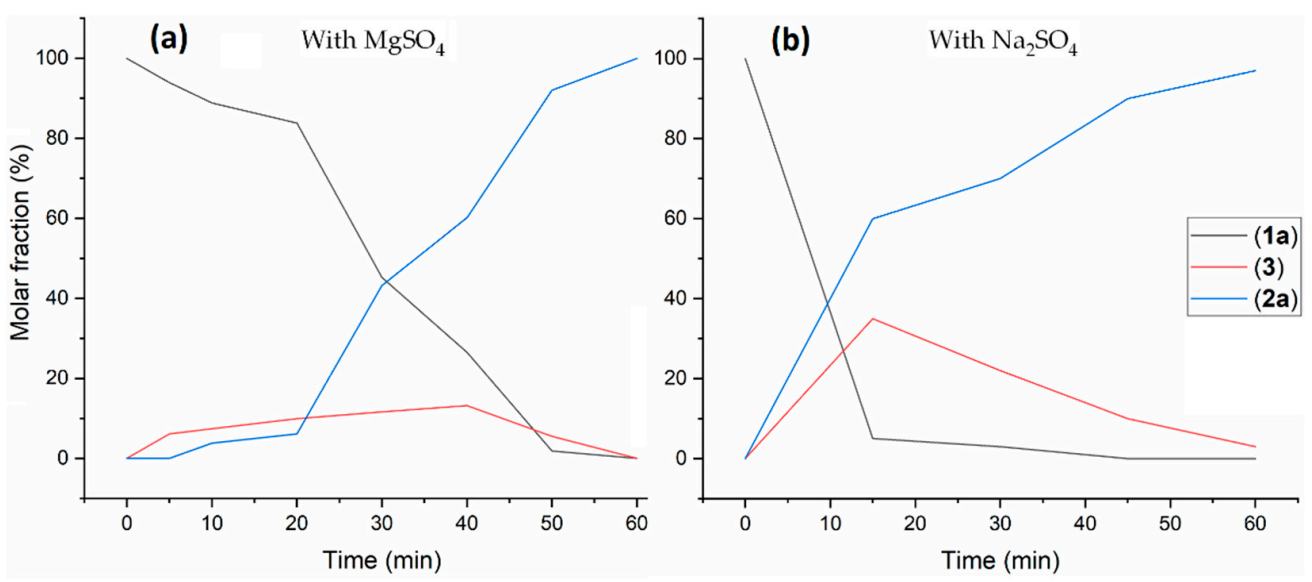

Figure 2. Monitoring the reaction of furfural with aniline using either $\mathrm{MgSO}_{4}$ as drying agent (a) or $\mathrm{Na}_{2} \mathrm{SO}_{4}$ as drying agent (b). Reactions were carried out using $1.3 \mathrm{mmol}$ of furfural, 1.2 equivalent aniline, and $1.3 \mathrm{mmol}$ of drying agent in $7 \mathrm{~mL} i \mathrm{PrOH}$.

Therefore, although $\mathrm{Na}_{2} \mathrm{SO}_{4}$ and molecular sieves demonstrate higher conversion rates than $\mathrm{MgSO}_{4}$, the latter drying agent was chosen due to the higher yield provided 
after $1 \mathrm{~h}$ of reaction time. Therefore, the conditions described in the Entry 5 in Table 2 were defined as standard conditions for the scope.

To assess the general applicability of the Ru-MACHO-BH as a catalyst for the one-pot synthesis of furfurylamines from furfurals and amines, various anilines were evaluated using the standard conditions (Scheme 3). Generally, moderate to excellent yields were obtained. The parent aniline afforded an excellent $93 \%$ of isolated product. Comparing the anilines containing either electron-donating or -withdrawing substituents, the latter group showed superior yield. As such, 4- $-\mathrm{C}_{6} \mathrm{H}_{4} \mathrm{NH}_{2}, 4-\mathrm{CF}_{3}-\mathrm{C}_{6} \mathrm{H}_{4} \mathrm{NH}_{2}$, and 4-aminopyridine generated the best yields of the substituted anilines with $74-95 \%$ of isolated products $2 \mathbf{h}-\mathbf{j}$. The product $\mathbf{2} \mathbf{j}$ is analogous to the anti-hepatitis-B compound shown in Figure 1, which demonstrates the direct applicability of the method for the synthesis of pharmacological activity compounds. On the other hand, a donating group $\left(4-\mathrm{CH}_{3}-\mathrm{C}_{6} \mathrm{H}_{4} \mathrm{NH}_{2}\right)$ afforded lower yield of $61 \%$ of $2 \mathrm{~d}$. This observation can perhaps be explained by the increased electronic deficiency of the imines when employing $4-\mathrm{CF}_{3}-\mathrm{C}_{6} \mathrm{H}_{4} \mathrm{NH}_{2}$ as reagent [1]. Various halogens were tested as well and showed moderate to good yields $(\mathbf{2} \mathbf{b}, \mathbf{2 e}, \mathbf{2} \mathbf{h})$. Compounds with substituent in different positions, such as 3-Cl- $\mathrm{C}_{6} \mathrm{H}_{4} \mathrm{NH}_{2}$ and 2- $-\mathrm{F}_{6} \mathrm{C}_{6} \mathrm{H}_{4} \mathrm{NH}_{2}$, showed good tolerance, yielding $60 \%$ and $56 \%$ of $2 \mathrm{c}$ and $2 \mathrm{f}$, respectively. The method was also tested with the secondary amine $\mathrm{N}$-methylaniline, which afforded the tertiary amine $\mathbf{2} \mathbf{g}$ in high yield (89\%). Unfortunately, no products were observed when employing various primary and secondary alkyl amines $\left(t \mathrm{BuNH}_{2}, n \mathrm{HepNH}_{2}, \mathrm{Me}_{2} \mathrm{NH}\right.$, morpholine).
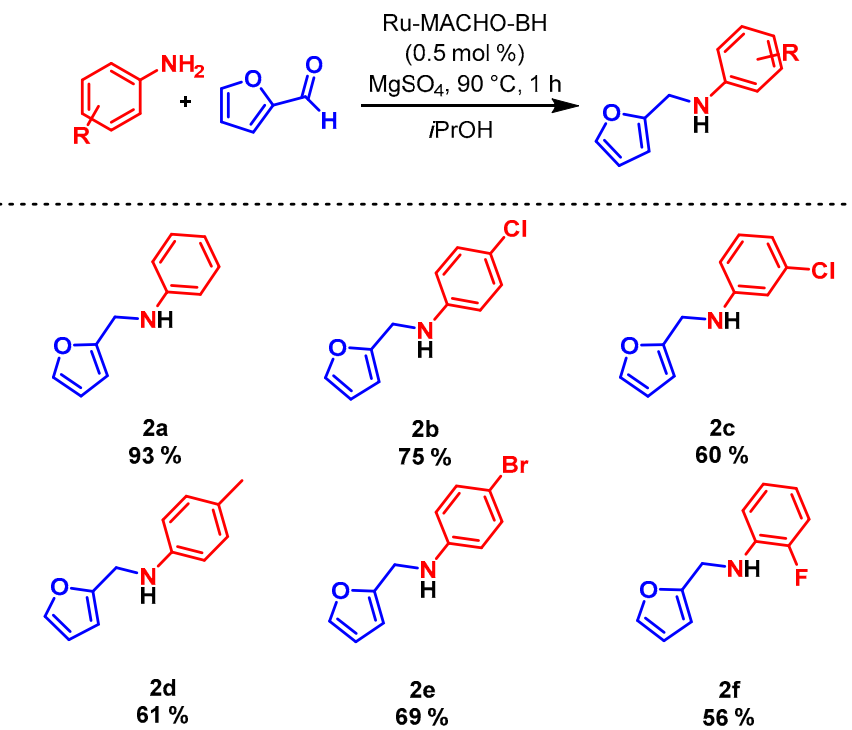

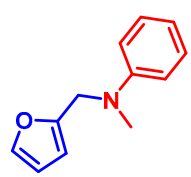

$2 \mathrm{~g}$
$89 \%$ 2d $61 \%$

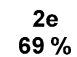

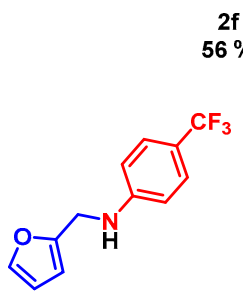

$2 i$
$77 \%$

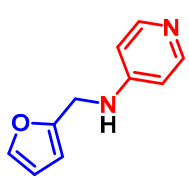

2j

Scheme 3. One-pot synthesis of furfurylamines catalyzed by Ru-MACHO-BH. Reactions were carried out using $1.3 \mathrm{mmol}$ of furfural, $1.56 \mathrm{mmol}$ of aniline, and $1.3 \mathrm{mmol}$ of $\mathrm{MgSO}_{4}$ in $7 \mathrm{~mL} i \mathrm{PrOH}$. All yields are isolated.

5-(hydroxymethyl)furfural (HMF) and 5-methylfurfural are other important biomassderived furans with industrial applications [60,61]. The furfurylamines derived from HMF are used in the synthesis of biopolymers (polyamides) and pharmaceuticals [4]. The $N$-(5-methylfurfuryl)aniline is a very important compound used in the synthesis of epoxyisonindoles and bioactive compounds such as anti-bacterial, anti-tuberculosis, antitumor, and anti-inflammatory entities [62-70]. Therefore, the method is an interesting 
alternative for the production of these valuable compounds. Hence, we also evaluated this compound as a potential substrate (Scheme 4). The reactions afforded a high yield of 4 $(87 \%)$ and a moderate yield of $5(54 \%)$.
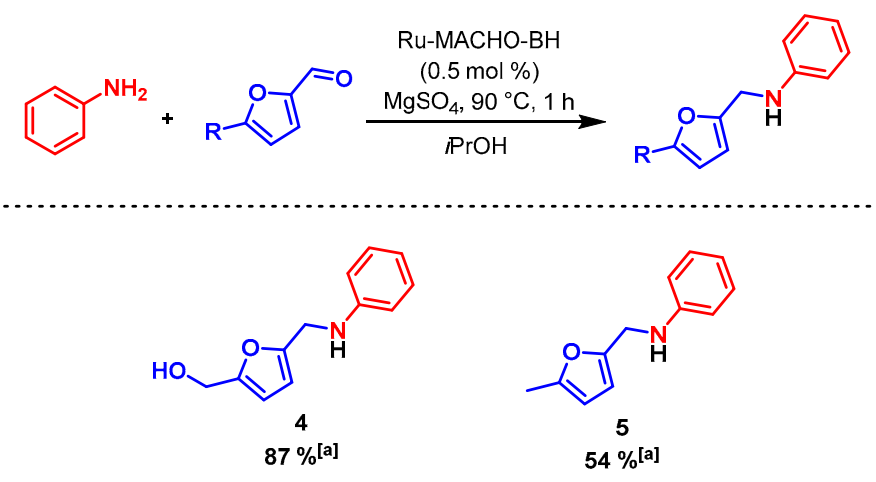

Scheme 4. One-pot synthesis of furfurylamines catalyzed by Ru-MACHO-BH. Reactions were carried out using $1.3 \mathrm{mmol}$ of furfural, $1.56 \mathrm{mmol}$ of aniline and $1.3 \mathrm{mmol}$ of $\mathrm{MgSO}_{4}$ in $7 \mathrm{~mL}$ of $i \mathrm{PrOH}$. [a] Isolated yield.

\section{Materials and Methods}

\subsection{Materials}

Most chemicals were purchased from commercial suppliers and used without further purification unless otherwise stated. Hydroxymethylfurfural (HMF, 99\%) (Sigma-Aldrich, St. Louis, MO, USA), furfural (99\%) (Sigma-Aldrich, St. Louis, MO, USA), 5-methylfurfural (99\%, Sigma-Aldrich, St. Louis, MO, USA), KOtBu (99\%, Sigma-Aldrich, St. Louis, MO, USA), $i \mathrm{PrOH}$ (anhydrous, 99.5\%, Sigma-Aldrich, St. Louis, MO, USA), Ru-MACHO (SigmaAldrich, St. Louis, MO, USA), and Ru-MACHO-BH (Strem Chemicals, Newburyport, MA, USA) are commercially available and were used without further purification. All reactions dealing with air or moisture-sensitive compounds were performed using standard Schlenk techniques or in an argon-filled glovebox. The ${ }^{1} \mathrm{H}$ and ${ }^{13} \mathrm{C}$ NMR spectra were recorded on a Bruker Avance III $400 \mathrm{MHz}$ spectrometer (Bruker, Billerica, MA, USA) and were referenced to the solvent peak. The software MestReNova version 11.0.0-17609 (Mestrelab, Escondido, CA, USA, 2016) was used for NMR analysis. The software OriginPro 2019 9.6.0.172 (Academic) (OriginLab, Northampton, MA, USA, 2019) was used for graphic plot. All the products are literature known compounds, and the experimental data $\left({ }^{1} \mathrm{H}\right.$ and ${ }^{13} \mathrm{C}\left\{{ }^{1} \mathrm{H}\right\}$ NMR spectra) fit those reported.

\subsection{Methods}

\subsubsection{Preparation of Aldimine 1a}

A mixture of furfural $(54 \mathrm{mmol})$, aniline $(54 \mathrm{mmol})$ and methanol $(0.5 \mathrm{M})$ in the presence of MS (4 $\AA$ ) was stirred at room temperature for $3 \mathrm{~h}$. After completion of the reaction, the crude mixture was filtered off and evaporated under reduced pressure. The product 1a was obtained as a brown oil, $7.83 \mathrm{~g}, 85 \%$.

3.2.2. General Procedure for Transfer Hydrogenation of Aldimine 1a Catalyzed by Ru-PNP Complexes

A Schlenk pressure vessel containing catalyst, additive and magnetic bar was sealed and flushed with argon (three times). The solvent and $\mathrm{H}$-donor $(i-\mathrm{PrOH})$ was introduced by a needle and stirred at $90^{\circ} \mathrm{C}$. After $10 \mathrm{~min}$, the aldimine 1a was added to the solution. After a certain reaction time (5-18 h), the reaction was stopped, and the crude was analyzed. The conversion was determined by spectroscopy ${ }^{1} \mathrm{H}$ NMR. 


\subsubsection{General Procedure for One-Pot Reductive Amination of Furfural}

In a Schlenk pressure vessel containing Ru-MACHO-BH (0.5 mol \%) and $\mathrm{MgSO}_{4}$ $(1.3 \mathrm{mmol})$, a magnetic stirring bar was added and the vessel was sealed and flushed with argon (three times). During argon flow, $4.5 \mathrm{~mL}$ of $i \mathrm{PrOH}$ was introduced by a needle and the solution was heated at $90{ }^{\circ} \mathrm{C}$ and stirred for $10 \mathrm{~min}$. In a flame-dried screw-cap vial, aniline $(1.56 \mathrm{mmol})$ and furfural $(1.3 \mathrm{mmol})$ were mixed with $2.5 \mathrm{~mL}$ of $i \mathrm{PrOH}$ (to provide a solution with furfural concentration of $0.18 \mathrm{M}$ ) under argon flow. The atmosphere was replaced with argon and the solution was introduced to the Schlenk pressure vessel. The reaction mixture was kept at $90{ }^{\circ} \mathrm{C}$ for $1 \mathrm{~h}$. The crude reaction mixture was evaporated under reduced pressure, and the product was obtained after purification through chromatography column (Ethyl acetate/pentane, 90:10). For the optimization process, the method of employing relative conversions as measured by NMR was confirmed with respect to absolute values by a single duplicate test reaction using mesitylene as internal standard.

\section{Conclusions}

In conclusion, we report the first example of an efficient base free one-pot transfer hydrogenative reductive amination of furfural for the synthesis of furfurylamines under mild conditions, employing low amounts of the commercially available catalyst Ru-MACHO-BH and $\mathrm{PrOH}$ as $\mathrm{H}$ donor. The general applicability of the method is demonstrated by the use of furfural and various anilines with different substituents, which afforded yields that varied from moderate to excellent (56-93\%). Furthermore, this chemoselective methodology established a high yield (83\%) in the synthesis of the furfurylamine derived from HMF and a moderate yield (54\%) from $N$-(5-methylfurfuryl)aniline.

Supplementary Materials: The following are available online at https: / www.mdpi.com/article / 10.3390 / catal11050558/s1, Table S1: Monitoring the reaction of furfural and aniline using $\mathrm{MgSO}_{4}$ as drying agent. Table S2: Monitoring the reaction of furfural and aniline using $\mathrm{Na}_{2} \mathrm{SO}_{4}$ as drying agent. Figure S1: ${ }^{1} \mathrm{H}$ NMR spectrum of $1 \mathbf{a}\left(400 \mathrm{MHz}, \mathrm{CDCl}_{3}\right)$, Figure S2: ${ }^{13} \mathrm{C}$ NMR spectrum of 1a $\left(100 \mathrm{MHz}, \mathrm{CDCl}_{3}\right)$, Figure S3: ${ }^{1} \mathrm{H} \mathrm{NMR}$ spectrum of $2 \mathrm{a}\left(400 \mathrm{MHz}, \mathrm{CDCl}_{3}\right)$, Figure S4: ${ }^{13} \mathrm{C} \mathrm{NMR}$ spectrum of $\mathbf{2 a}\left(100 \mathrm{MHz}, \mathrm{CDCl}_{3}\right)$, Figure S5: ${ }^{1} \mathrm{H} \mathrm{NMR}$ spectrum of $\mathbf{2} \mathbf{b}\left(400 \mathrm{MHz}, \mathrm{CDCl}_{3}\right)$, Figure S6: ${ }^{13} \mathrm{C} \mathrm{NMR} \mathrm{spectrum} \mathrm{of} \mathbf{2 b}\left(100 \mathrm{MHz}, \mathrm{CDCl}_{3}\right)$, Figure S7: ${ }^{1} \mathrm{H}$ NMR spectrum of $\mathbf{2 c}\left(400 \mathrm{MHz}, \mathrm{CDCl}_{3}\right)$, Figure S8: ${ }^{13} \mathrm{C}$ NMR spectrum of $2 \mathrm{c}\left(100 \mathrm{MHz}, \mathrm{CDCl}_{3}\right)$, Figure S9: ${ }^{1} \mathrm{H}$ NMR spectrum of $2 \mathrm{~d}(400 \mathrm{MHz}$, $\left.\mathrm{CDCl}_{3}\right)$, Figure S10: ${ }^{13} \mathrm{C} \mathrm{NMR}$ spectrum of $2 \mathrm{~d}\left(100 \mathrm{MHz}, \mathrm{CDCl}_{3}\right)$, Figure $\mathrm{S} 11:{ }^{1} \mathrm{H} \mathrm{NMR}$ spectrum of 2e $\left(400 \mathrm{MHz}, \mathrm{CDCl}_{3}\right)$, Figure S12: ${ }^{13} \mathrm{C} \mathrm{NMR}$ spectrum of $2 \mathbf{e}\left(100 \mathrm{MHz}, \mathrm{CDCl}_{3}\right)$, Figure S13: ${ }^{1} \mathrm{H} \mathrm{NMR}$ spectrum of $\mathbf{2 f}\left(400 \mathrm{MHz}, \mathrm{CDCl}_{3}\right)$, Figure S14: ${ }^{13} \mathrm{C} \mathrm{NMR}$ spectrum of $\mathbf{2 f}\left(100 \mathrm{MHz}, \mathrm{CDCl}_{3}\right)$, Figure S15: ${ }^{1} \mathrm{H}$ NMR spectrum of $\mathbf{2 g}\left(400 \mathrm{MHz}, \mathrm{CDCl}_{3}\right)$, Figure S16: ${ }^{13} \mathrm{C} \mathrm{NMR}$ spectrum of $\mathbf{2 g}\left(100 \mathrm{MHz}, \mathrm{CDCl}_{3}\right)$, Figure S17: ${ }^{1} \mathrm{H}$ NMR spectrum of $\mathbf{2 h}\left(400 \mathrm{MHz}, \mathrm{CD}_{3} \mathrm{OD}\right)$, Figure S18: ${ }^{13} \mathrm{C}$ NMR spectrum of $\mathbf{2 h}$ $\left(100 \mathrm{MHz}, \mathrm{CDCl}_{3}\right)$, Figure S19: ${ }^{1} \mathrm{H}$ NMR spectrum of $2 \mathbf{i}\left(400 \mathrm{MHz}, \mathrm{CDCl}_{3}\right)$, Figure S20: ${ }^{13} \mathrm{C} \mathrm{NMR}$ spectrum of $\mathbf{2 i}\left(100 \mathrm{MHz}, \mathrm{CDCl}_{3}\right)$, Figure S21: ${ }^{1} \mathrm{H} \mathrm{NMR}$ spectrum of $\mathbf{2} \mathbf{j}\left(400 \mathrm{MHz}, \mathrm{CDCl}_{3}\right)$, Figure S22: ${ }^{13} \mathrm{C}$ NMR spectrum of $2 \mathrm{j}\left(100 \mathrm{MHz}, \mathrm{CDCl}_{3}\right)$, Figure $\mathrm{S} 23:{ }^{1} \mathrm{H}$ NMR spectrum of $4\left(400 \mathrm{MHz}, \mathrm{CDCl}_{3}\right)$, Figure S24: ${ }^{13} \mathrm{C}$ NMR spectrum of $4\left(100 \mathrm{MHz}, \mathrm{CDCl}_{3}\right)$, Figure S25: ${ }^{1} \mathrm{H}$ NMR spectrum of $5(400 \mathrm{MHz}$, $\left.\mathrm{CDCl}_{3}\right)$, Figure S26: ${ }^{13} \mathrm{C} \mathrm{NMR}$ spectrum of $5\left(100 \mathrm{MHz}, \mathrm{CDCl}_{3}\right)$.

Author Contributions: D.L.J.P. did the experimental part. M.N. did funding acquisition and project administration. Everything else, from conceptualization to manuscript writing, D.L.J.P. and M.N. did equally. All authors have read and agreed to the published version of the manuscript.

Funding: This work was supported by a research grant (19049) from VILLUM FONDEN.

Conflicts of Interest: The authors declare no conflict of interest.

\section{References}

1. Caetano, J.A.T.; Fernandes, A.C. One-pot synthesis of amines from biomass resources catalyzed by $\mathrm{HReO}_{4}$. Green Chem. 2018, 20, 2494-2498. [CrossRef]

2. Dunbabin, A.; Subrizi, F.; Ward, J.M.; Sheppard, T.D.; Hailes, H.C. Furfurylamines from biomass: Transaminase catalysed upgrading of furfurals. Green Chem. 2017, 19, 397-404. [CrossRef] 
3. Mariscal, R.; Maireles-Torres, P.; Ojeda, M.; Sádabaa, I.; Granados, M.L. Furfural: A renewable and versatile platform molecule for the synthesis of chemicals and fuels. Energy Environ. Sci. 2016, 9, 1144-1189. [CrossRef]

4. He, J.; Chen, L.; Liu, S.; Song, K.; Yang, S.; Riisager, A. Sustainable access to renewable N-containing chemicals from reductive amination of biomass-derived platform compounds. Green Chem. 2020, 22, 6714-6747. [CrossRef]

5. Chieffi, G.; Braun, M.; Esposito, D. Continuous reductive amination of biomass-derived molecules over carbonized filter paper-supported FeNi alloy. ChemSusChem 2015, 8, 3590-3594. [CrossRef]

6. Deng, D.; Kita, Y.; Kamata, K.; Hara, M. Low-Temperature Reductive Amination of Carbonyl Compounds over Ru Deposited on $\mathrm{Nb}_{2} \mathrm{O}_{5} \cdot \mathrm{nH}_{2} \mathrm{O}$. ACS Sustain. Chem. Eng. 2019, 7, 4692-4698. [CrossRef]

7. Laroche, B.; Ishitani, H.; Kobayashi, S. Direct Reductive Amination of Carbonyl Compounds with $\mathrm{H}_{2}$ Using Heterogeneous Catalysts in Continuous Flow as an Alternative to N-Alkylation with Alkyl Halides. Adv. Synth. Catal. 2018, 360, 4699-4704. [CrossRef]

8. Gould, N.S.; Landfield, H.; Dinkelacker, B.; Brady, C.; Yang, X.; Xu, B. Selectivity Control in Catalytic Reductive Amination of Furfural to Furfurylamine on Supported Catalysts. ChemCatChem 2020, 12, 2106-2115. [CrossRef]

9. Murugesan, K.; Senthamarai, T.; Chandrashekhar, V.G.; Natte, K.; Kamer, P.C.J.; Beller, M.; Jagadeesh, R.V. Catalytic reductive aminations using molecular hydrogen for synthesis of different kinds of amines. Chem. Soc. Rev. 2020, 49, 6273-6328. [CrossRef] [PubMed]

10. Zhou, K.; Chen, B.; Zhou, X.; Kang, S.; Xu, Y.; Wei, J. Selective Synthesis of Furfurylamine by Reductive Amination of Furfural over Raney Cobalt. Chem CatChem 2019, 11, 5562-5569. [CrossRef]

11. Dong, C.; Wang, H.; Du, H.; Peng, J.; Cai, Y.; Guo, S.; Zhang, J.; Samart, C.; Ding, M. Ru/HZSM-5 as an efficient and recyclable catalyst for reductive amination of furfural to furfurylamine. Mol. Catal. 2020, 482, 110755. [CrossRef]

12. Carrillo, A.I.; Llanes, P.; Pericàs, M.A. A versatile, immobilized gold catalyst for the reductive amination of aldehydes in batch and flow. React. Chem. Eng. 2018, 3, 714-721. [CrossRef]

13. Maya, R.J.; Poulose, S.; John, J.; Varma, R.L. Direct Reductive Amination of Aldehydes via Environmentally Benign Bentonite-Gold Nanohybrid Catalysis. Adv.Synth. Catal. 2017, 359, 1177-1184. [CrossRef]

14. Mirza-Aghayan, M.; Kalantari, M.; Boukherroub, R. Palladium oxide nanoparticles supported on graphene oxide: A convenient heterogeneous catalyst for reduction of various carbonyl compounds using triethylsilane. Appl. Organomet. Chem. 2019, 33, 1-11. [CrossRef]

15. Zhang, Q.; Li, S.; Zhu, M.; Liu, Y.; He, H.; Cao, Y. Direct reductive amination of aldehydes with nitroarenes using bio-renewable formic acid as a hydrogen source. Green Chem. 2016, 18, 2507-2513. [CrossRef]

16. Li, H.; Guo, H.; Su, Y.; Hiraga, Y.; Fang, Z.; Watanabe, M.; Lee, R.; Smith, R.L., Jr.; Hensen, E.J.M. N-formyl-stabilizing quasicatalytic species afford rapid and selective solvent-free amination of biomass-derived feedstocks. Nat. Commun. 2019, 10, 699. [CrossRef] [PubMed]

17. Guillena, G.; Ramo, D.J.; Yus, M. Hydrogen Autotransfer in the N-Alkylation of Amines and Related Compounds using Alcohols and Amines as Electrophiles. Chem. Rev. 2010, 110, 1611-1641. [CrossRef] [PubMed]

18. Irrgang, T.; Kempe, R. Transition-metal-catalyzed reductive amination employing hydrogen. Chem. Rev. 2020, 120, 9583-9674. [CrossRef] [PubMed]

19. Wang, Y.; Furukawa, S.; Fu, X.; Yan, N. Organonitrogen chemicals from oxygen-containing feedstock over heterogeneous catalysts. ACS Catal. 2020, 10, 311-335. [CrossRef]

20. Saberi, A.A. Recent advances in percolation theory and its applications. Phys. Rep. 2015, 578, 1-32. [CrossRef]

21. Chen, W.; Sun, Y.; Du, J.; Si, Z.; Tang, X.; Zeng, X.; Lin, L.; Liu, S.; Lei, T. Preparation of 5-(Aminomethyl)-2-furanmethanol by direct reductive amination of 5-Hydroxymethylfurfural with aqueous ammonia over the Ni/SBA-15 catalyst. J. Chem. Technol. Biotechnol. 2018, 93, 3028-3034. [CrossRef]

22. Nuzhdin, A.L.; Bukhtiyarova, M.V.; Bukhtiyarova, G.A. Cu-Al mixed oxide derived from layered double hydroxide as an efficient catalyst for continuous-flow reductive amination of aromatic aldehydes. J. Chem. Technol. Biotechnol. 2020, 95, 3292-3299. [CrossRef]

23. Nuzhdin, A.L.; Simonov, P.A.; Bukhtiyarova, G.A.; Eltsov, I.V.; Bukhtiyarov, V.I. Reductive amination of 5-acetoxymethylfurfural over $\mathrm{Pt} / \mathrm{Al}_{2} \mathrm{O}_{3}$ catalyst in a flow reactor. Mol. Catal. 2021, 499, 111297. [CrossRef]

24. Galkin, K.I.; Ananikov, V.P. The Increasing Value of Biomass: Moving From C6 Carbohydrates to Multifunctionalized Building Blocks via 5-(hydroxymethyl)furfural. ChemistryOpen 2020, 9, 1135-1148. [CrossRef]

25. Lancien, A.; Wojcieszak, R.; Cuvelier, E.; Duban, M.; Dhulster, P.; Paul, S.; Dumeignil, F.; Froidevaux, R.; Heuson, E. Hybrid Conversion of 5-Hydroxymethylfurfural to 5-Aminomethyl-2-furancarboxylic acid: Toward New Bio-sourced Polymers. ChemCatChem 2021, 13, 247-259. [CrossRef]

26. Yang, Z.Y.; Hao, Y.C.; Hu, S.Q.; Zong, M.H.; Chen, Q.; Li, N. Direct Reductive Amination of Biobased Furans to N-Substituted Furfurylamines by Engineered Reductive Aminase. Adv. Synth. Catal. 2021, 363, 1033-1037. [CrossRef]

27. García-Ortiz, A.; Vidal, J.D.; Climent, M.J.; Concepción, P.; Corma, A.; Iborra, S. Chemicals from Biomass: Selective Synthesis of N-Substituted Furfuryl Amines by the One-Pot Direct Reductive Amination of Furanic Aldehydes. ACS Sustain. Chem. Eng. 2019, 7, 6243-6250. [CrossRef]

28. Wei, D.; Bruneau-Voisine, A.; Dubois, M.; Bastin, S.; Sortais, J.B. Manganese-Catalyzed Transfer Hydrogenation of Aldimines. ChemCatChem 2019, 11, 5256-5259. [CrossRef] 
29. Tanaka, K.; Miki, T.; Murata, K.; Yamaguchi, A.; Kayaki, Y.; Kuwata, S.; Ikariya, T.; Watanabe, M. Reductive amination of ketonic compounds catalyzed by CP*Ir(III) complexes bearing a picolinamidato ligand. J. Org. Chem. 2019, 84, 10962-10977. [CrossRef]

30. Yang, M.L.; Wu, Y.X.; Liu, Y.; Qiu, J.J.; Liu, C.M. A novel bio-based AB2 monomer for preparing hyperbranched polyamides derived from levulinic acid and furfurylamine. Polym. Chem. 2019, 10, 6217-6226. [CrossRef]

31. Chatterjee, M.; Ishizaka, T.; Kawanami, H. Reductive amination of furfural to furfurylamine using aqueous ammonia solution and molecular hydrogen: An environmentally friendly approach. Green Chem. 2016, 18, 487-496. [CrossRef]

32. Piccirilli, L.; Pinheiro, D.L.J.; Nielsen, M. Recent progress with pincer transition metal catalysts for sustainability. Catalysts 2020, 10, 773. [CrossRef]

33. Wang, D.; Astruc, D. The Golden Age of Transfer Hydrogenation. Chem. Rev. 2015, 115, 6621-6686. [CrossRef]

34. Wang, C.; Wu, X.; Xiao, J. Broader, greener, and more efficient: Recent advances in asymmetric transfer hydrogenation. Chem. Asian J. 2008, 3, 1750-1770. [CrossRef]

35. Farrar-tobar, R.A.; Dell'Acqua, A.; Tin, S.; de Vries, J.G. Metal-catalysed selective transfer hydrogenation of $\alpha$, $\beta$-unsaturated carbonyl compounds to allylic alcohols. Green Chem. 2020, 22, 3323-3357. [CrossRef]

36. Clapham, S.E.; Hadzovic, A.; Morris, R.H. Mechanisms of the H2-hydrogenation and transfer hydrogenation of polar bonds catalyzed by ruthenium hydride complexes. Coord. Chem. Rev. 2004, 248, 2201-2237. [CrossRef]

37. Werkmeister, S.; Neumann, J.; Junge, K.; Beller, M. Pincer-Type Complexes for Catalytic (De)Hydrogenation and Transfer (De)Hydrogenation Reactions: Recent Progress. Chem. Eur. J. 2015, 21, 12226-12250. [CrossRef]

38. Farrar-Tobar, R.A.; Wozniak, B.; Savini, A.; Hinze, S.; Tin, S.; de Vries, J.G. Base-Free Iron Catalyzed Transfer Hydrogenation of Esters Using EtOH as Hydrogen Source. Angew. Chem. Int. Ed. 2019, 58, 1129-1133. [CrossRef] [PubMed]

39. Clarke, Z.E.; Maragh, P.T.; Dasgupta, T.P.; Gusev, D.G.; Lough, A.J.; Abdur-Rashid, K. A family of active iridium catalysts for transfer hydrogenation of ketones. Organometallics 2006, 25, 4113-4117. [CrossRef]

40. Castellanos-blanco, N.; Arévalo, A.; García, J.J. Nickel-catalyzed transfer hydrogenation of ketones using ethanol as a solvent and a hydrogen donor. Dalt. Trans. 2016, 45, 13604-13614. [CrossRef]

41. Aboo, A.H.; Begum, R.; Zhao, L.; Farooqi, Z.H.; Xiao, J. Methanol as hydrogen source: Chemoselective transfer hydrogena- tion of $\alpha, \beta$-unsaturated ketones with a rhodacycle. Chin. J. Catal. 2019, 40, 1795-1799. [CrossRef]

42. Farrar-tobar, R.A.; Wei, Z.; Jiao, H.; Hinze, S.; Vries, J.G. De Selective Base-free Transfer Hydrogenation of $\alpha, \beta-U n s a t u r a t e d$ Carbonyl Compounds using $i \mathrm{PrOH}$ or EtOH as Hydrogen Source. Chem. Eur.J. 2018, 24, 2725-2734. [CrossRef]

43. Padilla, R.; Koranchalil, S.; Nielsen, M. Efficient and selective catalytic hydrogenation of furanic aldehydes using well defined Ru and Ir pincer complexes. Green Chem. 2020, 22, 6767-6772. [CrossRef]

44. Padilla, R.; Nielsen, M.; Jørgensen, M.S.B. Efficient catalytic hydrogenation of alkyl levulinates to $\gamma$-valerolactone. Green Chem. 2019, 21, 5195-5200. [CrossRef]

45. Garbe, M.; Wei, Z.; Tannert, B.; Spannenberg, A.; Jiao, H.; Bachmann, S.; Scalone, M.; Junge, K.; Beller, M. Enantioselective Hydrogenation of Ketones using Different Metal Complexes with a Chiral PNP Pincer Ligand. Adv. Synth. Catal. 2019, 361, 1913-1920. [CrossRef]

46. Guan, C.; Pan, Y.; Ang, E.P.L.; Hu, J.; Yao, C.; Huang, M.H.; Li, H.; Lai, Z.; Huang, K.W. Conversion of $\mathrm{CO}_{2}$ from air into formate using amines and phosphorus-nitrogen $\mathrm{PN}^{3} \mathrm{P}-\mathrm{Ru}(\mathrm{ii})$ pincer complexes. Green Chem. 2018, 20, 4201-4205. [CrossRef]

47. Neumann, J.; Bornschein, C.; Jiao, H.; Junge, K.; Beller, M. Hydrogenation of Aliphatic and Aromatic Nitriles Using a Defined Ruthenium PNP Pincer Catalyst. Eur. J. Org. Chem. 2015, 2015, 5944-5948. [CrossRef]

48. Filonenko, G.A.; Van Putten, R.; Schulpen, E.N.; Hensen, E.J.M.; Pidko, E.A. Highly efficient reversible hydrogenation of carbon dioxide to formates using a ruthenium PNP-pincer catalyst. ChemCatChem 2014, 6, 1526-1530. [CrossRef]

49. Filonenko, G.A.; Hensen, E.J.M.; Pidko, E.A. Mechanism of $\mathrm{CO}_{2}$ hydrogenation to formates by homogeneous Ru-PNP pincer catalyst: From a theoretical description to performance optimization. Catal. Sci. Technol. 2014, 4, 3474-3485. [CrossRef]

50. Oldenhuis, N.J.; Dong, V.M.; Guan, Z. Catalytic acceptorless dehydrogenations: Ru-Macho catalyzed construction of amides and imines. Tetrahedron 2014, 70, 4213-4218. [CrossRef]

51. Agapova, A.; Alberico, E.; Kammer, A.; Junge, H.; Beller, M. Catalytic Dehydrogenation of Formic Acid with Ruthenium-PNPPincer Complexes: Comparing N-Methylated and NH-Ligands. ChemCatChem 2019, 11, 1910-1914. [CrossRef]

52. Bertoli, M.; Choualeb, A.; Lough, A.J.; Moore, B.; Spasyuk, D.; Gusev, D.G. Osmium and ruthenium catalysts for dehydrogenation of alcohols. Organometallics 2011, 30, 3479-3482. [CrossRef]

53. Alberico, E.; Lennox, A.J.J.; Vogt, L.K.; Jiao, H.; Baumann, W.; Drexler, H.J.; Nielsen, M.; Spannenberg, A.; Checinski, M.P.; Junge, H.; et al. Unravelling the Mechanism of Basic Aqueous Methanol Dehydrogenation Catalyzed by Ru-PNP Pincer Complexes. J. Am. Chem. Soc. 2016, 138, 14890-14904. [CrossRef]

54. Nielsen, M.; Alberico, E.; Baumann, W.; Drexler, H.J.; Junge, H.; Gladiali, S.; Beller, M. Low-temperature aqueous-phase methanol dehydrogenation to hydrogen and carbon dioxide. Nature 2013, 495, 85-89. [CrossRef]

55. Sponholz, P.; Mellmann, D.; Cordes, C.; Alsabeh, P.G.; Li, B.; Li, Y.; Nielsen, M.; Junge, H.; Dixneuf, P.; Beller, M. Efficient and Selective Hydrogen Generation from Bioethanol using Ruthenium Pincer-type Complexes. ChemSusChem 2014, 7, $2419-2422$. [CrossRef]

56. Li, Y.; Nielsen, M.; Li, B.; Dixneuf, P.H.; Junge, H.; Beller, M. Ruthenium-catalyzed hydrogen generation from glycerol and selective synthesis of lactic acid. Green Chem. 2015, 17, 193-198. [CrossRef] 
57. Nielsen, M.; Junge, H.; Kammer, A.; Beller, M. Towards a green process for bulk-scale synthesis of ethyl acetate: Efficient acceptorless dehydrogenation of ethanol. Angew. Chem. Int. Ed. 2012, 51, 5711-5713. [CrossRef]

58. Dub, P.A.; Gordon, J.C. The role of the metal-bound N-H functionality in Noyori-type molecular catalysts. Nat. Rev. Chem. 2018, 2, 396-408. [CrossRef]

59. Kuriyama, W.; Matsumoto, T.; Ogata, O.; Ino, Y.; Aoki, K.; Tanaka, S.; Ishida, K.; Kobayashi, T.; Sayo, N.; Saito, T. Catalytic Hydrogenation of Esters. Development of an Efficient Catalyst and Processes for Synthesising (R)-1,2-Propanediol and 2-(lMenthoxy)ethanol. Org. Process Res. Dev. 2012, 16, 166-171. [CrossRef]

60. Hu, L.; Lin, L.; Wu, Z.; Zhou, S.; Liu, S. Recent advances in catalytic transformation of biomass-derived 5-hydroxymethylfurfural into the innovative fuels and chemicals. Renew. Sustain. Energy Rev. 2017, 74, 230-257. [CrossRef]

61. Hou, Q.; Qi, X.; Zhen, M.; Qian, H.; Nie, Y.; Bai, C.; Zhang, S.; Bai, X.; Ju, M. Biorefinery roadmap based on catalytic production and upgrading 5-hydroxymethylfurfural. Green Chem. 2021, 23, 119-231. [CrossRef]

62. Xiao, J.; Jin, Q.; Yang, J.; Xiong, L.; Qiu, J.; Jiang, J.; Peng, Y.; Li, T.; Qiu, Z.; Yang, W. Catalytic Synthesis of N-(5Methylfurfuryl)aniline from Bio-Derived Carbohydrates. Asian J. Org. Chem. 2019, 8, 328-334. [CrossRef]

63. Zubkov, F.I.; Nikitina, E.V.; Galeev, T.R.; Zaytsev, V.P.; Khrustalev, V.N.; Novikov, R.A.; Orlova, D.N.; Varlamov, A.V. General synthetic approach towards annelated 3a,6-epoxyisoindoles by tandem acylation/IMDAF reaction of furylazaheterocycles. Scope and limitations. Tetrahedron 2014, 70, 1659-1690. [CrossRef]

64. Wu, J.; Darcel, C. Iron-Catalyzed Hydrogen Transfer Reduction of Nitroarenes with Alcohols: Synthesis of Imines and Aza Heterocycles. J. Org. Chem. 2021, 86, 1023-1036. [CrossRef]

65. Ge, C.; Sang, X.; Yao, W.; Zhang, L.; Wang, D. Unsymmetrical indazolyl-pyridinyl-triazole ligand-promoted highly active iridium complexes supported on hydrotalcite and its catalytic application in water. Green Chem. 2018, 20, 1805-1812. [CrossRef]

66. Weickmann, D.; Frey, W.; Plietker, B. Synchronizing steric and electronic effects in $\left\{\mathrm{Ru}^{\mathrm{II}}(\mathrm{NNNN}, \mathrm{P})\right\}$ complexes: The catalytic dehydrative alkylation of anilines by using alcohols as a case study. Chem. Eur. J. 2013, 19, 2741-2748. [CrossRef]

67. Iovel, I.; Golomba, L.; Popelis, J.; Grinberga, S.; Lukevics, E. Synthesis and hydrosilylation of furan and thiophene N- methylenefluoroanilines in the presence of $\mathrm{Pd}(\mathrm{I})$ complex. Chem. Heterocycl. Compd. 2005, 41, 1112-1118. [CrossRef]

68. Lim, C.H.; Kudisch, M.; Liu, B.; Miyake, G.M. C-N Cross-Coupling via Photoexcitation of Nickel-Amine Complexes. J. Am. Chem. Soc. 2018, 140, 7667-7673. [CrossRef]

69. Ware, R.W.; Hinkley, L.A.; Hardeman, K.P.; Jenks, M.G. Substituted Quinoline and Quinazoline Inhibitors of Quinone Reductase 2. U.S. Patent Application No. WO2006034235A3, 6 April 2006.

70. Nuzhdin, A.L.; Bukhtiyarova, M.V.; Bukhtiyarov, V.I. Two-Step One-Pot Reductive Amination of Furanic Aldehydes Using $\mathrm{CuAlOx}$ Catalyst in a Flow Reactor. Molecules 2020, 25, 4771. [CrossRef] 